\title{
Effects of Corporate Governance on Financial Performance of Commercial Banks in Nigeria
}

\author{
Panan Danladi Gwaison* and Livinus Nkuri Maimako** \\ *Economics Department Nigeria Police Academy Wudil-Kano \\ **Accounting Department University of Jos \\ *Panan_gwaison@yahoo.com,**mrmaimakolivinus@gmail.com
}

\begin{abstract}
In most developing countries, several cases of collapses or failure in the banking sector were witnessed. Nigeria had witnessed several cases and collapsed in the banking sector. This study investigated the effects of corporate governance on the financial performance of commercial banks in Nigeria. The study used the survey research design. A secondary source of data was used for this research. The data were collected from financial statements of the five (5) commercial banks selected from the Nigerian Stock Exchange listing for fourteen financial years (2003 - 2017). The study utilized the panel Least Squares Regression Analysis as the method. The result indicated that board size had significant effects on financial performance (ROA) of commercial banks in Nigeria, board composition had significant effects on financial performance (ROA) of commercial banks in Nigeria, board gender diversity had significant effects on financial performance (ROA) of commercial banks in Nigeria, the audit committee has no significant effects on financial performance (ROA) of commercial banks in Nigeria, and board independence had significant effects on financial performance (ROA) of commercial banks in Nigeria. The study, therefore, concludes that the weak corporate governance structure in Nigeria contributed immensely to the recent crisis experienced in the Nigerian banking sector. The study recommended that banks develop and implement strategic training for board members and senior bank managers. Nigerian banks should appropriately adopt the international codes of corporate governance to meet the need of the Nigerian environment, among other recommendations.
\end{abstract}

Keywords: audit committee; board gender diversity; board independence; board size; board composition; financial performance.

\section{Citation}

Gwaison, P. D., \& Maimako, L. N. (2021). Effects of corporate governance on financial performance of commercial banks in Nigeria. International Journal of Finance Research, 2(1). 13-23. https://doi.org/10.47747/ijfr.v2i1.244

\section{Introduction}

In most developing countries, several cases of collapses or failure in the banking sector were witnessed. Nigeria had witnessed several cases and collapsed in the banking sector. Some examples include Savannah Bank Plc, Society Generale Bank Ltd, Oceanic Bank, Bank of the North, AfriBank, and Mainstream Bank. With the failure in Nigerian banks and the activities of some of the bank operators, there are concerns about the need to strengthen corporate governance in banks. This will boost public confidence and ensure efficient and effective functioning of the banking system (Soludo, 2004)

In Nigeria, corporate governance has been given the front burner status by all sectors of the 
economy. This is in recognition of the failure of the critical role of corporate governance in the success or failure of companies (Ogbechie, 2006). Corporate governance is about building credibility, ensuring transparency and accountability, and maintaining an effective channel of information disclosure that will foster remarkable corporate performance. Corporate governance can therefore be said to refer to the processes and structures by which the business and affairs of institutions are directed and managed in order to improve long-term shareholders' value by enhancing corporate performance and accountability while taking into account the interest of other stakeholders (Tricker, 2009).

In recent times, many country leaders have increased concern over corporate governance due to increased reported cases of frauds, insider trading, and agency conflicts, among other corporations saga (Enobakhare, 2010). Corporate failure has been recently witnessed in both developed and developing countries with the reported cases of the East Asia crises of 1997/98, the collapse of Enron in 2001 and WorldCom in 2002 (Inyang, 2009), and the justended global financial crisis of 2007/8. The crises emanated from the poor governance practices from the financial sector (the mortgage market). Since the mortgage market was the mother of the crisis, this has triggered the world leaders to enact some laws, increasing banks' governance. The World Bank is currently helping many economies in undertaking banking sector reformation and restructuring. This exercise will ease, reduce or eliminate some fatal global macroeconomic troubles which have emanated from poor governance of large financial and non-financial institutions (Zaharia, Tudorescu \& Aharia, 2010). Against this background, this study seeks to explore the effects of corporate governance on the financial performance of commercial banks in Nigeria. The main objective of this study is to investigate the effects of corporate governance such as board composition, the board size, board gender diversity, board audit committee, and board independence on the financial performance of commercial banks (ROA) in Nigeria.

\section{Literature Review}

\subsection{Corporate Governance}

Larcker and Tayan (2011) view corporate governance as the collection of control mechanisms that an organization adopts to prevent or dissuade potentially self-interest managers from engaging in activities detrimental to the welfare of shareholders and other stakeholders. At a minimum, the monitoring system consists of a board of directors to oversee management and an external auditor to express an opinion on the reliability of financial statements. In most cases, however, governance systems are influenced by a much broader group of constituents, including owners of the firm, creditors, labour unions, customers, suppliers, investment analysts, the media, and regulators.

Okafor (2012) posits that corporate governance connotes the processes involved in the discharge of the mandate of governance in corporate entities. These processes enable the realization of the underlying objective of corporate governance, which is to maximize shareholders' value without compromising the legitimate expectations of other stakeholders.

The concept of corporate governance explains how a company should be run by those put in charge of the company's affairs. Therefore, the centrality of the board of directors in the institutionalization of the tenets of sound corporate governance in every company cannot be denied. The prominence of the board of directors in corporate governance is evident in model definitions of corporate governance which in a nutshell regards corporate governance as the 
processes and structures by which the business and affairs of an institution are directed and managed in order to improve long-term shareholder value by enhancing corporate performance and accountability while taking into account the interest of other stakeholders. (Tricker, 2009).

\subsection{Financial Performance}

There are many different ways to measure financial performance, but all measures should be taken in aggregation. Line items such as revenues from operations, operating income, or cash flow from operations can be used, as well as total unit sales. Bank performance refers to how well a bank is doing, especially its profitability index and income statement. To understand how well a bank is doing, we need to start by looking at a bank's income statement, describing the sources of income and expenses that affect the bank's profitability. The bank's profitability can also be seen as a measure of its return on asset (ROA) (Emeka and Bello, 2016).

Santos and Brito (2012) identified that superior financial performance, which can be represented by profitability, growth, and market value, underpins corporate governance practice in organizations. Profitability measures a firm's past ability to generate returns, while growth demonstrates its past ability to increase its size. Increasing size, even at the same profitability level, will increase its absolute profit and cash generation. Their research shows that larger firm size can bring economies of scale and market power, leading to enhanced future profitability. On the other hand, the market value represents the external assessment and expectation of firms' future performance, which must correlate with historical profitability and growth levels while incorporating future market changes and competitive moves. The non-financial performance facets are customers satisfaction, employees' satisfaction, environmental performance, and social performance. But the study focus on the financial performance aspect (profitability).

George and Karibo (2014). defined it as the success in meeting pre-defined objectives, targets, and goals within a specified time target. Some of the aspects that must be considered when defining performance are time frame and its reference point. It is possible to differentiate between past and future performance. Moreover, it has been shown that past superior performance does not guarantee that it will remain superior in the future.

\subsection{Empirical Review}

Uwuigbe (2011) examined corporate governance and financial performance of banks in Nigeria. The variables used for corporate governance are board size, the proportion of nonexecutive directors, directors' equity interest, and the corporate governance disclosure index. The research used a regression analysis of panel data methodology was adopted while the content analysis technique, regression analysis, and t-test statistics were analyzed. It was observed from the study that a negative but significant relationship exists between board size, board composition, and the financial performance of these banks. At the same time, a positive and significant relationship was also noticed between directors' equity interest, level of governance disclosure, and performance.

Ahmad, Tariq, Hamad, and Hamad (2014) studied the link between corporate governance and a firm's financial performance using descriptive statistics. The correlation and regression analyses method were used to establish the link between the variables. The study found that board size and board composition have a positive impact on financial performance. 
Sanyaolu, Adesanmi, Imeokparia, Sanyaolu, \& Alimi (2017) examined the effect of corporate governance on the financial performance of listed deposit money banks in Nigeria from 20072016. The study used board size, audit committee, board independence, board gender diversity, and firm size as a proxy for corporate governance while financial performance was proxy with return on asset (ROA). The study randomly examined eight (8) deposit money banks listed on the Nigerian stock exchange and obtained data from the annual reports of the banks from 2007-2016. The data extracted were analyzed using pooled least square method of regression. The study found a significant negative relationship between board size, audit committee, firm size, and return on asset. However, the study found a positive and insignificant relationship between board independence and return on asset of the studied banks.

Udeh, Abiahu, and Tambou ( 2017) evaluated the impact of corporate governance on firms financial performance in Nigeria. Quoted Banks to determine the bank's financial performance before and after introducing the code of corporate governance in Nigeria. The main objective of this study is to evaluate board composition to determine its impact on firms financial performance. Board composition was used to measure corporate governance, while return on capital employed (ROCE) was used to operationalize financial performance. The study is anchored on the Shareholders Theory. The population of this study comprised fifteen (15) banks whose shares are quoted on the Nigeria Stock Exchange. The judgmental sampling technique was used to select seven (7) banks from the entire population of the study (which makes up the sample size). Data were obtained from a secondary source (published financial statements of the selected quoted banks) covering 2003 - 2014. The method of data analysis utilized was Ordinary Least Squares Regression Analysis. A model was formulated. The findings from this study showed that Board composition has a negative, though insignificant, impact on ROCE during the $2003-2008$ period and during the $2009-2014$ period.

Although there have been many studies on corporate governance in many countries worldwide, the majority of these studies have been conducted in developed nations. The methodology used in this study differs from the above-reviewed studies. Furthermore, the extent of the literature review indicates that none of the studies has investigated the effect of corporate governance in Nigeria using current data and other combinations of corporate governance mechanisms used in this study. The constitutes an important gap in the literature that necessitated this study.

\section{Research Method}

\subsection{Research design}

The study used the survey research design. The cross-sectional research technique's choice is the premise that the data used in this study was obtained at a specific point in time. The objective is to examine the effect of corporate governance on the financial performance of listed commercial banks in Nigeria.

A secondary source of data was used for this research. The data were collected from financial statements of the five (5) commercial banks selected from the Nigerian Stock Exchange listing for fourteen financial years $(2003$ - 2017). Namely, First Bank, Fidelity Bank, Zenith Bank, UBA, and GTB. In addition, the study utilized the panel Least Squares Regression Analysis as the method of data analysis.

\subsection{Population of the study}


The study population consists of all commercial banks whose shares are quoted on the Nigeria Stock Exchange as of December 31, 2017 (which are 15 out of the 21 banks operating in the country). Therefore, the population size is 15 banks. The data for this study is limited to the financial statement of listed banks whose annual reports are available on the Nigeria Stock Exchange (NSE) under the period of study $(2003-2017)$. These periods are chosen base on the availability of data.

\subsection{Sample and sampling technique}

This study employed a purposive or judgmental sampling technique to select five (5) commercial banks out of twenty-one (21) banks operating currently in Nigeria. Namely, First Bank, Fidelity Bank, Zenith Bank, UBA, and GTB. This selection is based only on banks whose shares are quoted on the Nigeria Stock Exchange (NSE) floor and whose financial statements are available. The technique is well suited for determining the sample as it provides an equal probability of selection and minimizes selection bias.

\subsection{Model specification}

To achieve the study's objective, the mathematical equation has been developed to investigate the effect of corporate governance on the financial performance of commercial banks in Nigeria. Hence, the corporate governance variables include; board size, board gender diversity, board independence, and audit committee, while return on asset (ROA) was used to measure the financial performance of the listed commercial banks. The data used for this study were obtained from the secondary source derived from the annual reports of the sampled banks listed on the Nigerian stock exchange (NSE) for fourteen (14) years from 2003-2017.

The following model was used to examine the relationship between the corporate governance variables on the financial performance of the firm;

$\mathrm{PERF}=\mathrm{ROA}$

PERF $=\mathrm{f}(\mathrm{BSIZE}, \mathrm{ACOM}, \mathrm{BIND}, \mathrm{BCOMP}, \mathrm{BGD})$

$\mathrm{ROA}=\beta 0+\beta 1 \mathrm{BSIZEit}+\beta 2 \mathrm{ACOMit}+\beta 3 \mathrm{BINDit}+\beta 4 \mathrm{BCOMPit}+\beta 5 \mathrm{BGDit}+\mu \mathrm{it}$

Where:

PERF $=$ Performance, BSIZE $=$ Board Size, $\mathrm{ACOM}=$ Audit Committee, $\mathrm{BGD}=$ Board Gender Diversity, FSIZE $=$ Firm Size, BIND $=$ Board Independence, $\mu=$ Stochastic error term/ random error term. $\mathrm{i}=$ Cross-section dimension and ranges from 1 to $\mathrm{n}$ number of period. $t=$ Time-series dimension and ranges from 1 to $t$ number of banks. $\beta 1, \beta 2, \beta 3, \beta 4$, and $\beta 5$ are the parameters to be estimated. $\beta 0=$ Intercept.

\section{Apriori expectation}

All explanatory variables are expected to have a positive impact on corporate governance. This can further be written as follows: $\beta 1, \beta 2, \beta 3, \beta 4, \beta 5>0$.

\section{Findings and Discussions}

\subsection{Pre-test: unit root test}

To evaluate stationarity or non-stationarity of variables, Lin, Levin, and Chu (LLC) tests were used. The results of the tests for all the variables in the model are shown in Table 1. 
Table 1. LLC Unit Root Test

\begin{tabular}{llcl}
\hline Variables & Statistics & P-Value & Order of Integration \\
\hline ROA & -3.14560 & 0.0008 & $1(1)$ \\
BSIZE & -2.49304 & 0.0063 & $1(1)$ \\
BCOMP & -5.62508 & 0.0000 & $1(1)$ \\
BGD & -3.23655 & 0.0006 & $1(0)$ \\
ACOM & -2.08078 & 0.0187 & $1(0)$ \\
BIND & -3.78915 & 0.0001 & $1(1)$ \\
\hline
\end{tabular}

Source: Authors Computation, 2020 (Eview-10.0)

Variables BGD and ACOM, based on LLC Tests, were found the stationary level I (0), but variables ROA, BIND, BCOMP, and BSIZE are not at the stationary level. However, the variable ROA, BIND, BCOMP, and BSIZE were found stationary at first difference 1(1)

Co-integration Estimate

Table-2. Pedroni Residual Cointegration Test

\begin{tabular}{|c|c|c|c|c|}
\hline \multicolumn{5}{|c|}{ Alternative hypothesis: common A.R. coefficient. (within-dimension) } \\
\hline & & & Weighted & \\
\hline & $\underline{\text { Statistic }}$ & Prob. & $\underline{\text { Statistic }}$ & Prob. \\
\hline Panel v-Statistic & 1.281813 & 0.1000 & -1.281887 & 0.9001 \\
\hline Panel rho-Statistic & 0.308766 & 0.6213 & 1.407418 & 0.9203 \\
\hline Panel PP-Statistic & -4.415029 & 0.0000 & -4.130378 & 0.0000 \\
\hline Panel ADF-Statistic & 2.442388 & 0.9927 & 0.059044 & 0.5235 \\
\hline
\end{tabular}

Alternative hypothesis: individual A.R. coefficient. (between-dimension)

\begin{tabular}{lcc} 
& Statistic & Prob. \\
\cline { 2 - 3 } Group rho-Statistic & 1.750011 & 0.9599 \\
Group PP-Statistic & -5.140160 & 0.0000 \\
Group ADF-Statistic & 1.374678 & 0.9154
\end{tabular}

Source: Authors Computation, 2020 (Eview-10.0)

As can be seen, according to Panel Statistic P.P.- and Panel ADF-Statistic (within-dimension Statistic) and Group P.P. - Statistic (between-dimension Statistic) test H0 hypothesis suggesting lack of cointegration is rejected, and cointegration or the existence of long-term equilibrium relationship between the variables of the model is accepted. Thus, the model shows a long-run equilibrium relationship among the six variables used in the analysis. It shows that the variables move together in the long run.

Table 3. Panel Least-Squares Error Correction Model Test

\begin{tabular}{lllll}
\hline \hline Variable & Coefficient & Std. Error & t-Statistic & Prob. \\
\hline \hline D(BSIZE) & -0.108044 & 0.204546 & -0.528211 & 0.5992 \\
D(BCOMP) & -0.529233 & 0.273821 & -1.932771 & 0.0577 \\
D(BGD) & 0.125467 & 0.270188 & 0.464368 & 0.6440 \\
D(ACOM) & 0.487723 & 0.335757 & 1.452608 & 0.1512 \\
D(BIND) & -0.045544 & 0.061448 & -0.741174 & 0.4613 \\
ECM(-1) & -0.418478 & 0.120854 & -3.462687 & 0.0010 \\
\hline \hline
\end{tabular}

Source: Authors Computation, 2020 (Eview-10.0) 
The ECM (-1) is highly significant. The coefficient of ECM -0.418478 suggests mild adjustment. Nearly 42 percent of the disequilibrium of the previous year's shock adjusts back to the long-run equilibrium in the current year. The results showed that the error correction term $\operatorname{ECM}(-1)$ is correctly specified. It satisfies a-priory expectations and statistically significant at the five percent level. The negative sign confirms our earlier conclusion that ROA and its regressors (variables of corporate governance) are indeed cointegrated, and the statistical significance of the error correction term implies disequilibrium in the long run.

\subsection{Estimated Regression Model}

Table 4. Results of Panel EGLS (Cross-Section Weights) The Model Estimation

\begin{tabular}{lllll}
\hline \hline Variable & Coefficient & Std. Error & t-Statistic & Prob. \\
\hline \hline C & 6.661554 & 1.315687 & 5.063174 & 0.0000 \\
BSIZE & 0.080806 & 0.070482 & 2.146475 & 0.0056 \\
BCOMP & -0.134871 & 0.107905 & -2.249904 & 0.0156 \\
ACOM & -0.142696 & 0.101803 & -0.401688 & 0.2655 \\
BGD & -0.034225 & 0.113406 & -3.301787 & 0.0037 \\
BIND & -0.055743 & 0.017041 & -3.271200 & 0.0017 \\
\hline \hline R-squared & 0.626293 & Mean dependent var & 6.976512 \\
Adjusted R-squared & 0.277473 & S.D. dependent var & 5.751320 \\
S.E. of regression & 3.457423 & Sum squared resid & 824.8105 \\
F-statistic & 6.683675 & Durbin-Watson stat & 1.955373 \\
Prob(F-statistic) & 0.000039 & & & \\
\hline \hline
\end{tabular}

Source: Authors Computation, 2020 (Eview-10.0)

$$
\begin{aligned}
& \mathrm{ROA}=\beta 0+\beta 1 \mathrm{BSIZEt}+\beta 2 \mathrm{ACOMt}+\beta 3 \mathrm{BINDt}+\beta 4 \mathrm{BCOMPt}+\beta 5 \mathrm{BGDt}+\mu \mathrm{t} \\
& \mathrm{ROA}=6.66+0.08 \mathrm{BSIZEt}-014 \mathrm{ACOMt}-0.056 \mathrm{BINDt}+013 \mathrm{BCOMPt}-0.034 \mathrm{BGDt}
\end{aligned}
$$

The F-statistic examines the overall significance of a regression model, including all the $\mathrm{K}$ variables. Therefore, by examining the overall fit and significance of the model, it could be observed that the model has a better fit. That is, the probability F-statistic value of 0.000039 is less than 0.05 . The coefficient of determination (R-square), used to measure the goodness of fit of the estimated model, indicates that the model is reasonably fit in prediction. That is, 62.62 percent change in ROA was due to BSIZE, BCOMP, ACOM, BGD, and BIND collectively, while the error term captured 37.38 percent unaccounted variations. It showed that BSIZE, BCOMP, ACOM, BGD, and BIND had a strong significant impact on the financial performance of commercial banks of the Nigerian economy.

The result further shows a negative and significant relationship between BCOMP, ACOM, BGD, and BIND on return on asset, which implies that a unit increase in BCOMP, ACOM, $\mathrm{BGD}$, and BIND will lead to a decrease in the return on asset of the sampled banks. The result also shows a positive and insignificant relationship between BSIZE and the return on asset of the sampled firms. This indicates that a unit increase in BSIZE will lead to an insignificant difference in the financial performance of the sampled banks.

Durbin Watson's (D.W.) statistic of 1.956 (approximately 2). It is indicating that there is no autocorrelation among the variables. It shows an unbiased estimate, and the model could be used for policy decisions. 


\subsection{Post- Estimation Diagnostics Tests}

Serial L.M. test: More so, the regression model is free of serial correlation going by the result of the serial L.M. test.

Table 5. Serial L.M. test:

\begin{tabular}{llcl}
\hline \hline Test & Statistic & d.f. & Prob. \\
\hline \hline Breusch-Pagan LM & 5.562572 & 10 & 0.8506 \\
Pesaran scaled LM & -0.992239 & & 0.3211 \\
Pesaran CD & -0.759441 & & 0.4476 \\
\hline \hline
\end{tabular}

Source: Authors Computation, 2020 (Eview-10.0)

From table 5. the P-value of Breusch-Pagan LM, Pesaran scaled L.M., and Pesaran CD were $0.8506,0.3211$, and 0.4476 , and were greater than 0.05 ; thus, we accept the null hypothesis that there is no serial correlation among the variables used in the model.

Normal Distribution Test

It is a test for the normality distribution assumption of the error term. The result shows the properties of the residuals. Significantly, the Jarque-Bera statistics test whether the residual from our equation violates the normality assumption of the OLS technique.

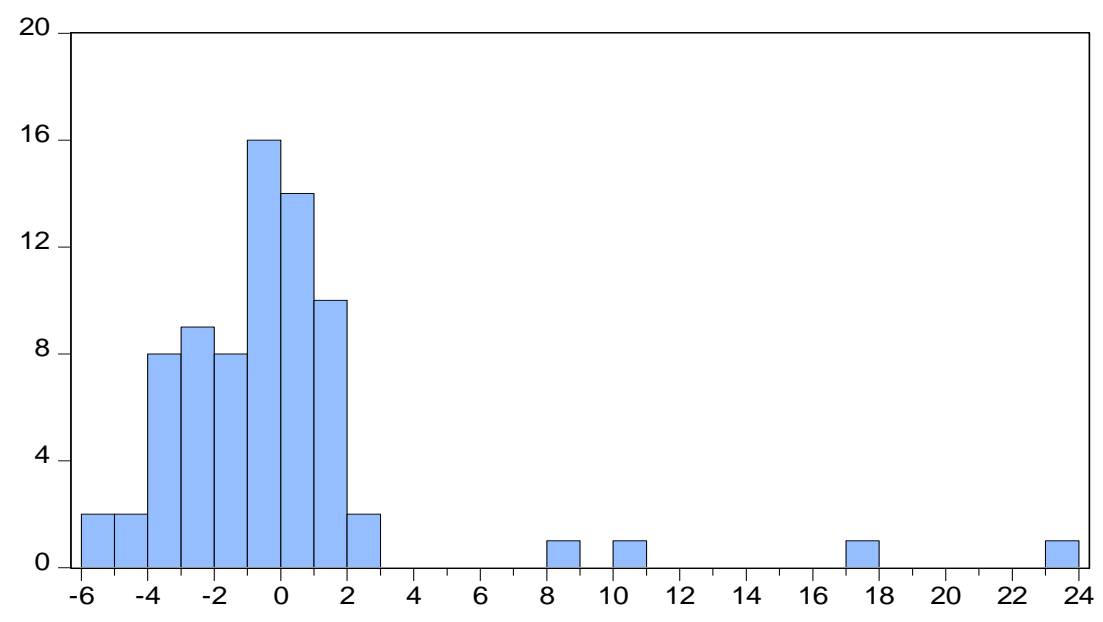

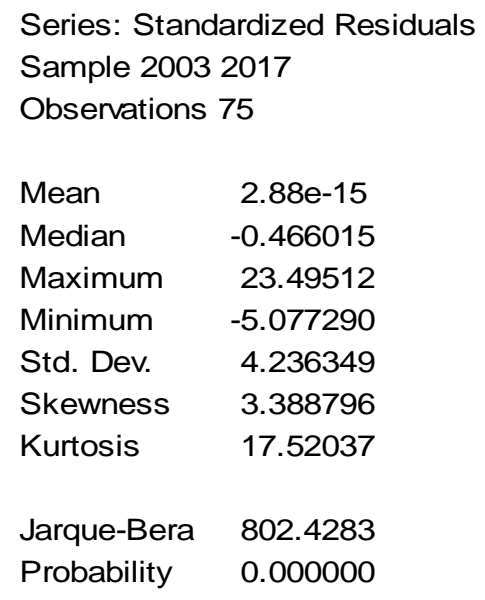

Figure 1. Source: Normal Distribution Test

Authors Computation, 2020 (Eview-10.0)

In figure 1, the hypothesis of non-normality is rejected since the p-value of the Jarque-Berra statistics is less than 0.05 (assuming a 5\% level of significance). Therefore, the residuals are normally distributed.

\subsection{Discussion of Findings}

From our research objectives above and our results, the parameter estimate of the board size (BSIZE) showed that it relates positively with the financial performance (ROA) of commercial banks in Nigeria and was found statistically significant. The obtained result is similar to Ahmad, Tariq, Hamad, and Hamad (2014), which shows that Board Size has a positive and significant impact on the financial performance of firms. In addition, KyereboahColeman and Biekpe (2006) concluded with a positive relationship between a firm's 
performance and board size. They argued that a large board size brings in more management skills and professionalism, making it very difficult for the CEO to manipulate the board.

The results above show that board compositions have a negative but significant impact on financial performance return on assets (ROA). These findings agreed with Udeh, Abiahu, and Tambou's (2017) findings, which show that board compositions had a negative relationship with the financial performance of quoted banks.

Audit committee size (ACOM) had a negative and insignificant relationship with the financial performance of quoted banks .this was in line with the works of Sanyaolu, Adesanmi, Imeokparia, Sanyaolu, \& Alimi (2017)

Board independence (BIND) and board gender diversity (BGB) are negatively but significantly related to the financial performance of quoted banks .this was in line with the works of Sanyaolu, Adesanmi, Imeokparia, Sanyaolu, \& Alimi (2017).

\section{Conclusion}

This study focused on finding out the triggers of financial performance in the banking sector, of which Corporate Governance proved to be an essential issue for many commercial banks. It has been established in selected literature that corporate governance affects stakeholders and the banks as a whole, corporate governance affects the potential or ability of a bank to reach its market share both domestically and globally, corporate governance also determines the banks' ability to fulfil its social objectives with its clientele and society at large. This study has also established that that corporate governance practices have measurable effects on banks' operational performances. The study, therefore, concludes that the weak corporate governance structure in Nigeria contributed immensely to the recent crisis experienced in the Nigerian banking sector.

Certain limitations were encountered in the course of this study. Key among these include Unavailability of Data, time and funds limitation, a variable used in the model, the model used and the methods of data analysis, and the sources of Data used.

This study empirically investigated the effect of corporate governance on the return on assets of banks in Nigeria as a proxy for financial performance. Other proxies for financial performance, such as return on equity (ROE), can also be used in further studies. The limitations of the study have prompted the researcher to recommend the following areas for further studies. Literature review indicates that most studies have been carried out on huge firms or banks. Further research should be devoted to small and medium-scale enterprises in Nigeria and Africa as a whole. This is because SMEs account for over $80 \%$ of the total number of enterprises found in this region and had several corporate governance issues. Further research is also required on non-financial aspects of firms and banks. A study comparing financial and non-financial aspects of firms or banks may most likely elicit variation in the relationship between corporate governance and the value of a firm.

\section{References}

Ahmad, N., M. S. Tariq., N. Hamad, and S. Hamad. (2014). An exploration of corporate governance and its relation with financial performance: A case study from banking institutions of Pakistan. Arabian Journal of Business and Management Review (Oman 
Chapter)4(1). 103-108

Emeka, E.E.and Bello A.I.E., (2016). The effect of corporate governance on bank's financial performance in Nigeria. Journal of Business and Management. 18(3). 99-107.

Enobakhare, A. (2010). Corporate governance and bank performance in Nigeria. Diss. Stellenbosch: University of Stellenbosch.

Inyang, B.J. (2009): Nurturing Corporate Governance System: The Emerging Trends in Nigeria. Journal of Business Systems, Governance and Ethics, 4(2). 1-13.

Coleman-Kyereboah. A. (2007). International conference on corporate governance in emerging markets. Sabanci University, Istanbul, Turkey. Composition, leadership structure and financial performance, Journal on Strategic Management, 19, 269-290.

Larcker, David F. and Tayan, Brian, (2011) Seven Myths of Executive Compensation. Rock Center for Corporate Governance at Stanford University Closer Look Series. Topics, Issues and Controversies in Corporate Governance No. CGRP-17, Available at SSRN: https://ssrn.com/abstract=1869019 or http://dx.doi.org/10.2139/ssrn.1869019.

Ogbechie, C. (2006). Corporate Governance: A Challenge For Nigerian Banks. Retrieved From www.Businessdayonline.Com On 26/04/2019.

Okafor, E.E (2012). Emerging nonstandard employment relations and implications for human resource management functions in Nigeria. African Journal of Business Management, 6(26), pp. 7612-7621. Available online at http://www.academicjournals.org/AJBM. DOI: 10.5897/AJBM11.2731.

Performance Of Microfinance Institutions (Mfis) In Ghana”, Working Paper 4330-05, UGBS, Legon.

Santos, J.B. \& Brito, L.A. (2012). Toward a Subjective Measurement Model for Firm Performance. Brazilian Administration Review, 9(5), http://dx.doi.org/10.1590/S180776922012000500007.

Sanyaolu, O. A., Adesanmi, A.D., Imeokparia, L., Sanyaolu, A. O., \& Alimi, A. (2017). Corporate governance and financial performance of quoted deposit money banks in Nigeria. International Journal of Social Science and Economic Research, 2(8) 4131-4146

Soludo, C.C. (2004). Consolidating the Nigerian Banking Industry to Meet the Development Challenges of the 21st Century. Being an Address to the Special Meeting of Bankers Committee, Held on July 6.

Tricker, B. (2009). Corporate Governance: Principles, Policies, and Practices. New York: Oxford University Press.

Udeh, F.N, Abiahu, M.C and Tambou, L.E. ( 2017). Impact $\mathrm{f}$ corporate governance on firms financial performance: a study of quoted banks in Nigeria. retrieved from Users/user/Documents/usman/ImpactofCorporateGovernanceonFirmsFinancialPerforma nce-AStudyofQuotedBanksinNigeria.pdf 16/4/2019

Uwuigbe, O.R. (2011). Corporate governance and financial performance of banks: A study of listed banks in Nigeria. Covenant University, Ota. 
Zaharia, C., Tudorescu, N., \& Zaharia, I. (2010). How bad governance practices inflicted systemic risks on the global economy. Economics, Management and Financial Markets, 5(1), 176.

\section{Copyrights}

Copyright for this article is retained by the author(s), with first publication rights granted to the journal.

This is an open-access article distributed under the terms and conditions of the Creative Commons Attribution license (http://creativecommons.org/licenses/by/4.0/) 